Original Article

\title{
INVESTIGATION OF THE NEUROPROTECTIVE EFFECT OF LINAGLIPTIN AND CELIPROLOL IN RESERPINE-INDUCED OROFACIAL DYSKINESIA AND ROTENONE-INDUCED NEURODEGENERATION IN RATS
}

\author{
VANDANA S. NADE ${ }^{1}$, VISHAL Y. MARDHEKAR ${ }^{2 *}$, UNNATI R. BHOYE ${ }^{1}$, LAXMAN A. KAWALE ${ }^{1}$ \\ ${ }^{1}$ Department of Pharmacology, M. V. P. S. College of Pharmacy, Nashik 422002, ${ }^{2}$ Department of Pharmaceutical Sciences, RTMNU, Nagpur 40001 \\ Email: vishalmardhekar143@gmail.com
}

Received: 15 Aug 2019, Revised and Accepted: 22 Oct 2019

\section{ABSTRACT}

Objective: Linagliptin, an anti-diabetic agent, proven to play an important role in regulating neuronal plasticity and reduce apoptosis and neuroinflammation by activating downstream AMPK/Sirt 1 pathway, which protects mitochondrial function and suppresses intracellular ROS accumulation and shows antioxidant action. Celiprolol, a $\beta$-1selective adrenoceptor blocker used as an anti-hypertensive agent, possesses a direct scavenging activity on oxygen radicals with antioxidant properties. The current study was designed to investigate the combined neuroprotective effect of linagliptin and celiprolol.

Methods: Wistar rats of either sex were divided into different groups $(n=6)$. Eight groups each for Reserpine induced orofacial dyskinesia model and Rotenone induced neurodegeneration model to mimic Parkinson's like conditions and treated or not with different doses of linagliptin and celiprolol. $24 \mathrm{~h}$ after the last dose, animals were subjected to behavioral, biochemical and histopathological evaluations. The data were analyzed by ANOVA and Bonferroni multiple comparison test.

Results: Reserpine treatment increased VCMs, tongue protrusion and decreased locomotor activity. Rotenone treatment decreases the motor activity and exploratory ability of the animals. Reserpine as well as rotenone treatments decrease catalase, GSH, SOD and increase the LPO levels as compared to sham group animals. Reserpine and rotenone also showed the presence of ghost cells and vacuolated cytoplasm. Linagliptin and celiprolol alone as well as in combination normalized the behavioral, biochemical and histopathological complications.

Conclusion: Linagliptin and Celiprolol showed neuroprotection by antioxidant activity as well as improved reserpine and rotenone-induced behavioral deficits. Both drugs have tenacious potential and can be used clinically with some further investigations.

Keywords: Linagliptin, Celiprolol, Antioxidant, Neuroprotection, Parkinson's disease

(C) 2020 The Authors. Published by Innovare Academic Sciences Pvt Ltd. This is an open-access article under the CC BY license (http://creativecommons.org/licenses/by/4.0/] DOI: http://dx.doi.org/10.22159/ijcpr.2020v12i1.36833. Journal homepage: https://innovareacademics.in/journals/index.php/ijcpr

\section{INTRODUCTION}

Neurodegenerative disorders are characterized by a slow and progressive loss of neuronal functions and sometimes death of neurons in the specific regions of the brain and spinal cord. It represents various neurodegenerative diseases, including Parkinson's disease (PD), Alzheimer's disease (AD), Amyotrophic Lateral Sclerosis (ALS), Huntington's disease (HD), and multiple sclerosis (MS). The etiology of these disorders is still unknown. It is believed that these disorders are a result of both genetic susceptibility and environmental factors. Several collective evidence showed that oxidative stress from an excessive generation of reactive oxygen species (ROS) and nitrogen species (NOS) plays a key role in the development of these disorders [1-2]. Parkinson's disease (PD) is the most common age-related neurodegenerative disorder and is characterized by the loss of dopaminergic neurons. It shows clinical symptoms including bradykinesia, tremor, and rigidity [3]. Recent studies investigated that oxidative stress is a crucial factor in the pathogenesis of PD [4-6]. The imbalance between Reactive Oxygen Species (ROS) production and activity of antioxidant system results in Oxidative stress, which in turn damages the proteins, lipids, and DNAs [7].

Linagliptin, generally used as an anti-diabetic agent, inhibits the DPP-4 enzyme [the enzyme responsible for rapid degradation of the glucagon-like peptide-1 (GLP-1)]. Central GLP-1 receptor stimulation has been proven to play an important role in regulating neuronal plasticity as well as survival and reduce apoptosis [8] to reduce neuroinflammation $[9,10]$ by subsequently activating downstream AMPK/Sirt 1 pathway, which protects mitochondrial function and suppresses intracellular ROS accumulation. Linagliptin also reported for its antioxidant action [11, 12]. Thus, Linagliptin can be effective in neurodegenerative disorders by decreasing oxidative stress and stimulating GLP-1 [9]. Celiprolol, a $\beta$-1selective adrenoreceptor blocker used as an anti-hypertensive agent, possesses a direct scavenging activity on oxygen radicals with antioxidant properties [13, 14], which could play a key role in neurodegenerative disorders.

The current study was designed to investigate the combined neuroprotective effect of linagliptin and celiprolol in reserpine-induced orofacial dyskinesia model and rotenone-induced neurodegeneration model. The effects of the tested drugs were compared to the standard neuroprotective drugs Vitamin E (Vit. E) [15-17] and LevodopaCarbidopa in the reserpine model and rotenone model, respectively.

\section{MATERIALS AND METHODS}

\section{Animals}

Male Wistar rats (200-250g) were housed in polypropylene cages and maintained under the standard laboratory environmental conditions at a temperature $-25 \pm 2{ }^{\circ} \mathrm{C}$ with $12 \mathrm{~h}$ light/dark cycle and $50 \pm 5 \%$ relative humidity and received food and water ad libitum. All the experiments were carried out during the light period. The studies were carried out in accordance with the guidelines given by Committee for the Purpose of Control and Supervision of Experiments on Animals (CPCSEA), New Delhi (India), and was approved by the Institutional Animal Ethical Committee of M. V. P. S College of Pharmacy under the number IAEC/2018/03.

\section{Drugs and reagent}

Reserpine (Research Lab, Mumbai, India), Rotenone (Sigma Aldrich, Mumbai, India) Linagliptin (Lupin Pharmaceuticals, Mumbai, India), Celiprolol and Levodopa-Carbidopa (Hetero Labs, Hyderabad, India), Vitamin E (Merck Ltd., Goa, India). Nitrobluetetrazolium Chloride (NBT) and 5,5'-Dithiobis (2-nitrobenzoic acid) (DTNB) (Alfa Aesar, A 
Johnson Mathey Company, Chennai, India), Acetylthiocholine iodide (Sigma Aldrich, USA) Bovine serum albumin (Spectrochem Pvt. Ltd., Mumbai, India) 2-Thiobarbituric acid (TBA), Ethylenediamine tetraacetic acid (ETDA), Folin-Ciocalteau reagent and Aluminium chloride (Research Lab, Fine Chem., Mumbai, India).

\section{Experimental design for reserpine-induced orofacial dyskinesia} in rats

The animals were divided into eight groups, Group I (Sham group) animals were received $0.2 \%$ PEG in distilled water, p. o., for $5 \mathrm{~d}$ and $0.1 \%$ acetic acid for $3 \mathrm{~d}$, every other day. Group II (Vehicle-treated group) animals received reserpine ( $1 \mathrm{mg} / \mathrm{kg} \mathrm{SC}$ ) in $0.1 \%$ acetic acid for $3 \mathrm{~d}$, every other day. Animals in Group III (Linagliptin $5 \mathrm{mg} / \mathrm{kg}$ ) and IV (Linagliptin $10 \mathrm{mg} / \mathrm{kg}$ ) were received Linagliptin at a dose 5 , and $10 \mathrm{mg} / \mathrm{kg}$, p. o. respectively for $5 \mathrm{~d}$ and reserpine for $3 \mathrm{~d}$, every other day. Rats in Group V (Celiprolol $50 \mathrm{mg} / \mathrm{kg}$ ) and VI (Celiprolol $100 \mathrm{mg} / \mathrm{kg}$ ) were received Celiprolol at a dose of 50 and $100 \mathrm{mg} / \mathrm{kg}$, p. o. respectively for $5 \mathrm{~d}$ along with reserpine. Group VII (Lina 10 $\mathrm{mg} / \mathrm{kg}+$ Celi $100 \mathrm{mg} / \mathrm{kg}$ ) animals have received a combination dose of Linagliptin+Celiprolol $(10 \mathrm{mg} / \mathrm{kg}+100 \mathrm{mg} / \mathrm{kg}$, p. o. $)$ along with reserpine, every other day. Group VIII (Vit. E $10 \mathrm{mg} / \mathrm{kg}$ ) animals received standard drug-Vitamin $\mathrm{E}$ for $5 \mathrm{~d}$ and reserpine for $3 \mathrm{~d}$, every other day. The first injection of acetic acid was given $24 \mathrm{~h}$ after the administration of PEG. A time interval of 30 min was maintained between the administration of test/standard drug and reserpine. On the fifth day, $24 \mathrm{~h}$ after the last reserpine injection, all the rats were observed for the quantification of orofacial dyskinesia. Animals were sacrificed about $1 \mathrm{~h}$ after behavioral measurements for various biochemical and histopathological assays.

\section{Quantification of dyskinesia}

To quantify the occurrence of oral dyskinesia on the test day, rats were placed individually into a small Plexiglas observation cage $(30 \times 20 \times$ $20 \mathrm{~cm}$ ) to score vacuous chewing movements (VCMs) and tongue protrusion frequencies. Animals were allowed $10 \mathrm{~min}$ to acclimatize to the observation cage before behavioral assessments were performed. Mirrors were placed under the floor and behind the back wall of the cage to permit observation of oral dyskinesia when the animal was faced away from the observer. The VCMs and tongue protrusions were defined as a single mouth opening in the vertical plane not directed towards physical material and visible extension of the tongue outside of the mouth respectively. If VCMs or tongue protrusions occurred during a period of grooming, they were not taken into account. The behavioral parameters of oral dyskinesia were measured continuously identity of the animals (Burger et al., for a15 min. In all the experiments, the observer was blind to the 2003).

\section{Assessment of total locomotor activity by digital photoactometer}

Locomotor activity is an index of alertness of mental activity as most of the drugs acting on CNS influence locomotor activity. It is measured with the help of photoactometer which operates on photoelectric cells that are connected with the circuit with the counter. Interruption of light beams as a measure of movements of rats in a cage has been used by many authors. When a beam of light falling on the photocell is cut-off by the animal, a count is recorded. Locomotion was measured up to $10 \mathrm{~min}$ for each rat $24 \mathrm{~h}$ after administration of the last dose of vehicle/drug [18].

\section{Experimental design for rotenone-induced neurodegeneration in rats}

The animals were divided into eight groups, Group I (Sham group) animals received WFI, p. o., for $21 \mathrm{~d}$ and Group II (Vehicle-treated group) animals received rotenone $3 \mathrm{mg} / \mathrm{kg}$, i. p. in PEG and DMSO in ratio 1:1 for $21 \mathrm{~d}$. Group III (Linagliptin $5 \mathrm{mg} / \mathrm{kg}$ ) and IV (Linagliptin $10 \mathrm{mg} / \mathrm{kg}$ ) received Linagliptin at a dose of $5,10 \mathrm{mg} / \mathrm{kg}$, p. o. respectively along with rotenone $3 \mathrm{mg} / \mathrm{kg}$, for $21 \mathrm{~d}$. Group $\mathrm{V}$ (Celiprolol $50 \mathrm{mg} / \mathrm{kg}$ ) and VI (Celiprolol $100 \mathrm{mg} / \mathrm{kg}$ ) received Celiprolol at a dose of 50 and $100 \mathrm{mg} / \mathrm{kg}, \mathrm{p}$. o. respectively along with rotenone. Group VII (Lina $10 \mathrm{mg} / \mathrm{kg}+$ Celi $100 \mathrm{mg} / \mathrm{kg}$ ) animals received combination dose of Linagliptin+Celiprolol $(10 \mathrm{mg} / \mathrm{kg}+100$ $\mathrm{mg} / \mathrm{kg}$, po.) along with rotenone. Group VIII (LevoCarbi $30 \mathrm{mg} / \mathrm{kg}$ ) animals received standard drug Levodopa-Carbidopa $(30 \mathrm{mg} / \mathrm{kg}$, p. o.) and rotenone ( $3 \mathrm{mg} / \mathrm{kg}, \mathrm{p}$. o.) for $21 \mathrm{~d}$. On the $21^{\text {st }}$ day, $24 \mathrm{~h}$ after the rotenone or vehicle injection, all the rats were observed for the behavioral tests. Animals were sacrificed about $1 \mathrm{~h}$ after behavioral measurements for biochemical and histopathological assays.

\section{Rotarod test}

The apparatus consists of a horizontal wooden rod or metal rod coated with rubber with $3 \mathrm{~cm}$ diameter attached to a motor with speed adjusted to 4 rotations per minute. The rod was $75 \mathrm{~cm}$ in length, having the 6 sections and $50 \mathrm{~cm}$ above from the tabletop. Cages below the sections serve to restrict the movements of the animals when they fall from the roller. All animals undergo a pretest on the apparatus. Only those animals which have demonstrated their ability to remain on the revolving rod for at least 1 minute were used for the test. The test compounds were administered intraperitoneally or orally. Thirty minutes after intraperitoneal or 60 min after oral administration, the rats were placed for 1 min on the rotating rod. The number of animals falling from the roller during this time was counted. The rotarod test was used to assess motor coordination and balance. Rats have to maintain their balance on a rotating rod. The rod was rotated at $4 \mathrm{rpm}$ and gradually increased to $20 \mathrm{rpm}$. The latency time required for the rat to fall off the rod rotating at different speeds or under continuous acceleration (e. g., from 4 to $20 \mathrm{rpm}$ ) was recorded [18].

\section{Hole and board}

The hole-board has a size of $40 \times 40 \mathrm{~cm} .16$ holes with a diameter of $3 \mathrm{~cm}$ each are distributed evenly on the floor. The animal's tendency to insert its head into the holes was observed and quantified. The board was elevated so that the rats poking its nose into the hole, does not see the bottom. Vehicle-treated, control and rotenone-treated animals were allowed to explore the holes in the board every day for $5 \mathrm{~min}$, and the total number of pokes per 5 min was recorded for each rat [18].

\section{Estimation of various antioxidant enzymes in rat brain}

\section{Tissue homogenate preparation}

On the last day, $1 \mathrm{~h}$ after all behavioral assessments, the animals were sacrificed by decapitation and brains were removed, followed by rinsing with isotonic saline solution and weighted. A $10 \%(\mathrm{w} / \mathrm{v})$ tissue homogenate was prepared in $0.1 \mathrm{M}$ phosphate buffer $(\mathrm{pH}$ 7.4). The post-nuclear fraction for catalase assay was obtained by centrifugation of the homogenate at $1000 \times \mathrm{g}$ for $20 \mathrm{~min}$ at $4{ }^{\circ} \mathrm{C}$ (Remi-C30, Remi Industries Ltd. Mumbai, India); for other enzyme assays, centrifugation was done at $12000 \mathrm{rpm}$ for $60 \mathrm{~min}$ at $4{ }^{\circ} \mathrm{C}$. Elico $0^{\mathrm{mm}} \mathrm{BL}$ 200 bio spectrophotometer was used for subsequent assays [19].

\section{Estimation of catalase}

Catalase activity was assayed by the method of Luck [30], wherein the breakdown of $\mathrm{H}_{2} \mathrm{O}_{2}$ is measured at $240 \mathrm{~nm}$. Briefly, the assay mixture consist of $3 \mathrm{ml}$ of $0.01 \mathrm{M} \mathrm{H}_{2} \mathrm{O}_{2}$ phosphate buffer $(\mathrm{pH} 7)$ and $0.05 \mathrm{ml}$ of the supernatant of tissue homogenate $(10 \%)$, the change in absorbance was recorded after $1 \mathrm{~min}$ at $240 \mathrm{~nm}$. Enzyme activity was calculated using the millimolar extinction coefficient of $\mathrm{H}_{2} \mathrm{O}_{2}$ (0.071). The results were expressed as $\mu \mathrm{M}$ of $\mathrm{H}_{2} \mathrm{O}_{2}$ decomposed per minute per milligram of protein.

\section{Estimation of reduced glutathione}

Reduced glutathione (GSH) in the brain was estimated according to the method of Ellman [31]. A $0.75 \mathrm{ml}$ sample of homogenate was precipitated with $0.75 \mathrm{ml}$ of $4 \%$ sulphosalicylic acid. The samples were centrifuged at $1200 \times \mathrm{g}$ for $15 \mathrm{~min}$ at $4{ }^{\circ} \mathrm{C}$. The assay mixture contained $0.5 \mathrm{ml}$ supernatant and $4.5 \mathrm{ml}$ of $0.01 \mathrm{M}$ DTNB $[5,5$ 'dithiobis (2-nitrobenzoic acid)] in $0.1 \mathrm{M}$ phosphate buffer (pH 8.0). The yellow color developed was read immediately at $412 \mathrm{~nm}$. The results were expressed as $\mu \mathrm{Mol}$ GSH per milligram of protein.

\section{Estimation of superoxide dismutase}

Superoxide dismutase activity was assayed according to the method of Kono [32], wherein the reduction of nitro blue tetrazolium chloride (NBT) was inhibited by the superoxide dismutase and measured at 560 $\mathrm{nm}$ spectrophotometrically. Briefly, the reaction was initiated by the addition of $0.1 \mathrm{ml}$ of $1 \mathrm{mmol}$ hydroxylamine hydrochloride to the reaction mixture containing $0.1 \mathrm{ml}$ of $0.1 \mathrm{~m}$ Methylene diamine 
tetraacetic acid (EDTA), $0.1 \mathrm{ml}$ of $24 \mu \mathrm{M} \mathrm{NBT}, 0.1 \mathrm{ml}$ of $0.03 \% \mathrm{v} / \mathrm{v}$ Triton X100 reagent and post-nuclear fraction of brain homogenate to make 1 $\mathrm{ml}$ final volume. The mixture was incubated at $37^{\circ} \mathrm{C}$ for $20 \mathrm{~min}$ and absorbance was measured at $560 \mathrm{~nm}$. Results were expressed as percentage inhibition of the reduction of NBT.

\section{Lipid peroxidation assay}

The quantitative measurement of lipid peroxidation in the brain was done by the method of Wills [33]. The amount of malondialdehyde (MDA) formed was measured by reaction with thiobarbituric acid at 532 $\mathrm{nm}$. The results were expressed as $\mathrm{nM}$ of MDA per milligram of protein using the molar extension coefficient of the chromophore $(1.56 \times 105 \mathrm{M}$ $1 \mathrm{~cm}-1$ ). The reaction mixture contains $0.1 \mathrm{ml}$ tissue homogenate, $0.2 \mathrm{ml}$ of $8 \%$ sodium lauryl sulphate (SLS), $1.5 \mathrm{ml}$ of $20 \%$ acetic acid, and $1.5 \mathrm{ml}$ of $0.8 \%$ thiobarbituric acid (TBA) solution. The mixture was heated at 95 ${ }^{\circ} \mathrm{C}$ for $1 \mathrm{~h}$ on a water bath. Then, $5 \mathrm{ml}$ mixture of n-butanol and pyridine (15:1 ratio) was added to it. The mixture was shaken vigorously and centrifuged at $2200 \times \mathrm{g}$ for $5 \mathrm{~min}$. The absorbance of the upper layer (organic layer) was measured at $532 \mathrm{~nm}$. The results were expressed as $\mathrm{nM}$ of MDA per milligram of tissue, using the molar extinction coefficient of the chromophore $(1.56 \times 105 \mathrm{M}-1 \mathrm{~cm}-1)$.

\section{Histopathological analysis}

Histopathological evaluation of the rat brains was performed. The brains were excised and immediately fixed in $10 \%$ buffered formalin. The cerebral cortex was sectioned from the brain, which was embedded in paraffin after being dehydrated in alcohol. Fivemicrometer thick serial histological sections were obtained from the paraffin blocks by using a microtome and stained with hematoxylin and eosin ( $\mathrm{H}$ and $\mathrm{E})$. The sections were examined under a light microscope (Olympus, Japan) and photomicrographs were taken.

\section{Statistical analysis}

Data were analyzed by one-way analysis of variance (ANOVA) followed by Bonferroni multiple comparison test. Data were represented as mean \pm SEM, $\mathrm{p}<0.05$ were considered as statistically significant.

\section{RESULTS}

\section{Reserpine-induced orofacial dyskinesia}

Effect of Linagliptin and Celiprolol on Vacuous chewing movements (VCM)

The vacuous chewing movement was examined $24 \mathrm{~h}$ after the last reserpine injection. Vehicle group resulted in a significant increase in VCM as compared to the sham group $(\mathrm{p}<0.001)$. Treatment with linagliptin $(5 \mathrm{mg} / \mathrm{kg}$ and $10 \mathrm{mg} / \mathrm{kg})$ and celiprolol $(50 \mathrm{mg} / \mathrm{kg})$ both alone as well as in combination at doses $10 \mathrm{mg} / \mathrm{kg}$ and $100 \mathrm{mg} / \mathrm{kg}$ respectively, we observed significant reduction in VCM $(\mathrm{p}<0.001$ each), when analyzed with one-way ANOVA. [Treatment $F(7,39)=$ 15.30, $\mathrm{p}<0.0001 ; \mathrm{n}=6$ ] as compared to vehicle group (fig. 1 ).

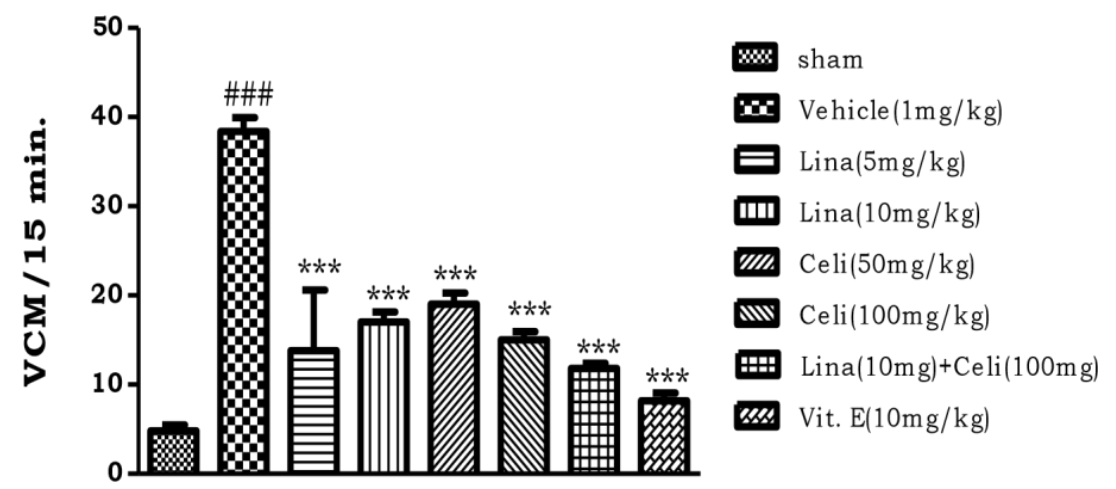

Fig. 1: Effect of linagliptin and celiprolol on vacuous chewing movements, each column represents mean \pm SEM of the shift in no. of vacuous chewing movements $(n=6) .{ }^{\# \# \#<0.001}$ vs sham and ${ }^{* * *} p<0.001$ vs vehicle

\section{Effect of linagliptin and celiprolol on tongue protrusions}

The tongue protrusions were examined $24 \mathrm{~h}$ after the last reserpine injection. Vehicle group resulted in a significant increase in tongue protrusions as compared to the sham group $(\mathrm{p}<0.001)$. Treatment with linagliptin $(5 \mathrm{mg} / \mathrm{kg}$ and $10 \mathrm{mg} / \mathrm{kg}$ ) and celiprolol $(50 \mathrm{mg} / \mathrm{kg})$ both alone as well as in combination at doses $10 \mathrm{mg} / \mathrm{kg}$ and 100 $\mathrm{mg} / \mathrm{kg}$ respectively, showed significant reduction in number of tongue protrusions $(\mathrm{p}<0.001$ each), when analyzed with one-way ANOVA. [Treatment $F(7,39)=84.15, p<0.0001 ; n=6]$ as compared to vehicle group (fig. 2).
Effect of linagliptin and celiprolol on total locomotor activity (TLA)

The TLA was examined $24 \mathrm{~h}$ after the last reserpine injection. Vehicle group resulted in a significant decrease in locomotion as compared to the sham group $(\mathrm{p}<0.001)$. Treatment with linagliptin $(5 \mathrm{mg} / \mathrm{kg}$ and $10 \mathrm{mg} / \mathrm{kg})$ and celiprolol $(50 \mathrm{mg} / \mathrm{kg})$ both alone as well as in combination at doses $10 \mathrm{mg} / \mathrm{kg}$ and $100 \mathrm{mg} / \mathrm{kg}$ respectively, showed a significant increase in locomotion $(\mathrm{p}<0.001$ each) when analyzed with one-way ANOVA. [Treatment $\mathrm{F}(7,39)=$ 28.79, $\mathrm{p}<0.0001 ; \mathrm{n}=6$ ] as compared to vehicle group (fig. 3 ).

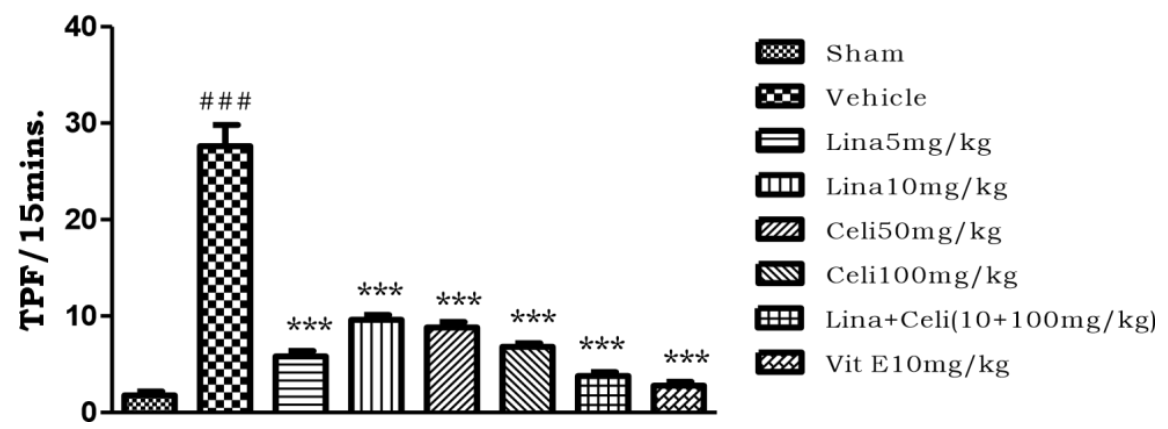

Fig. 2: Effect of linagliptin and celiprolol on tongue protrusions, each column represents mean \pm SEM of a shift in no. of tongue protrusions (n=6/group). ${ }^{\# \# p<0.001}$ vs sham and ${ }^{* * *} p<0.001$ vs vehicle 


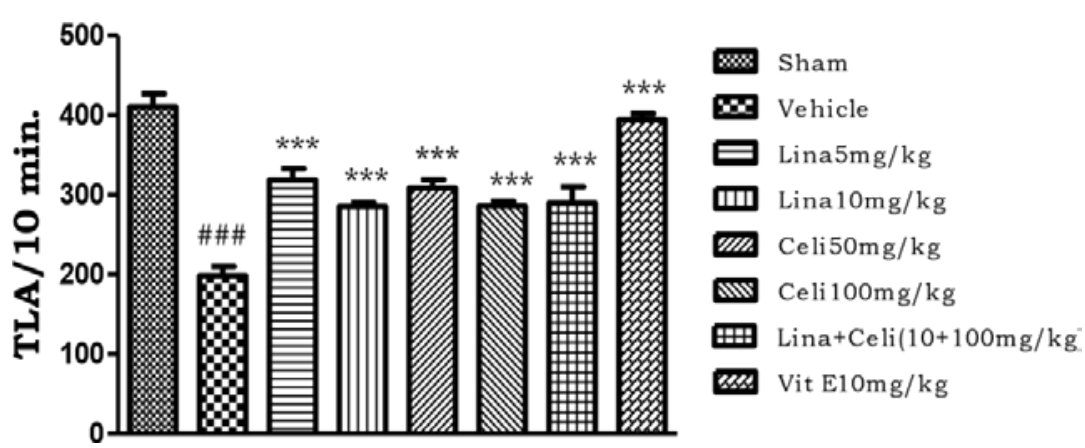

Fig. 3: Effect of linagliptin and celiprolol on TLA, each column represents the mean \pm SEM of a shift in total locomotor activity ( $n=6)$.

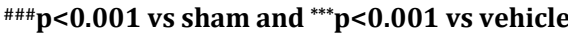

\section{Biochemical parameters}

All biochemical parameters were examined $24 \mathrm{~h}$ after the last reserpine injection

Effect of linagliptin and celiprolol on catalase (CAT) level in rat brain

Vehicle group resulted in a significant decrease in catalase levels as compared to the sham group $(\mathrm{p}<0.001)$. Treatment with linagliptin at a dose of $5 \mathrm{mg} / \mathrm{kg}$ but not $10 \mathrm{mg} / \mathrm{kg}$ showed a significant increase in catalase levels $(\mathrm{p}<0.001)$ and celiprolol at a dose of $100 \mathrm{mg} / \mathrm{kg}$ but not $50 \mathrm{mg} / \mathrm{kg}$, showed a significant increase in catalase levels $(\mathrm{p}<0.05)$. Moreover, both drugs in combination at doses $10 \mathrm{mg} / \mathrm{kg}$ and $100 \mathrm{mg} / \mathrm{kg}$ respectively, showed a significant increase in catalase levels $(\mathrm{p}<0.001)$, when analyzed with one-way ANOVA. $[$ Treatment $F(7,39)=19.43, p<0.0001 ; n=6]$ as compared to vehicle group (fig. 4)

Effect of linagliptin and celiprolol on reduced glutathione (GSH) level in rat brain

Vehicle group showed a significant decrease in GSH as compared to the sham group $(\mathrm{p}<0.001)$. Treatment with linagliptin $(5 \mathrm{mg} / \mathrm{kg}$ and $10 \mathrm{mg} / \mathrm{kg}$ ) and celiprolol $(50 \mathrm{mg} / \mathrm{kg}$ ) both alone as well as in combination at doses $10 \mathrm{mg} / \mathrm{kg}$ and $100 \mathrm{mg} / \mathrm{kg}$ respectively, showed significant increase in GSH level $(\mathrm{p}<0.001$ each), when analyzed with one-way ANOVA. [Treatment $F(7,39)=154.3$, $\mathrm{p}<0.0001 ; \mathrm{n}=6$ ] as compared to vehicle group (fig. 5).

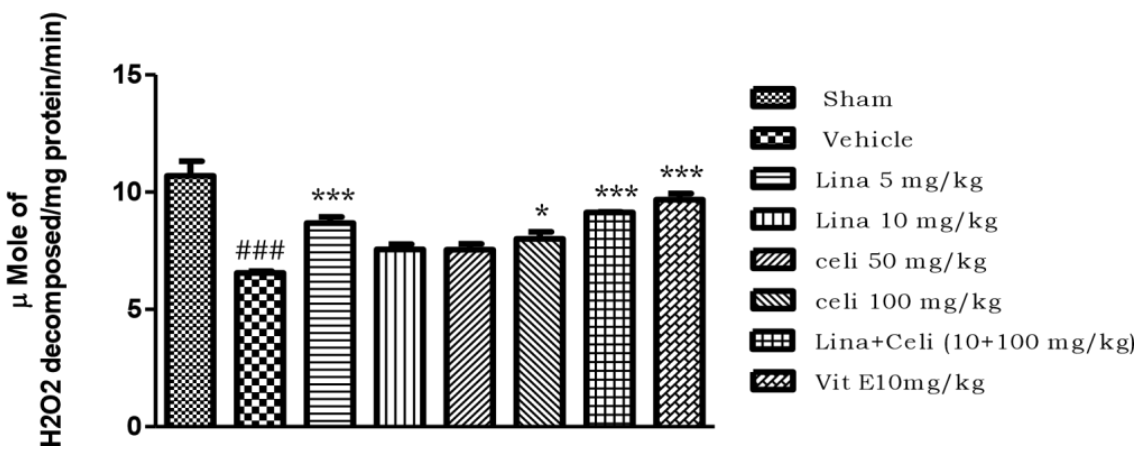

Fig. 4: Effect of linagliptin and celiprolol on catalase level, each column represents the mean $\pm S E M$ of a shift in the decomposition of $\mathrm{H}_{2} \mathrm{O}_{2 /} \min (\mathrm{n}=6)$. ${ }^{\# \# \#} \mathrm{p}<0.001$ vs sham and ${ }^{*} \mathrm{p}<0.05,{ }^{* * *} \mathrm{p}<0.001$ vs vehicle

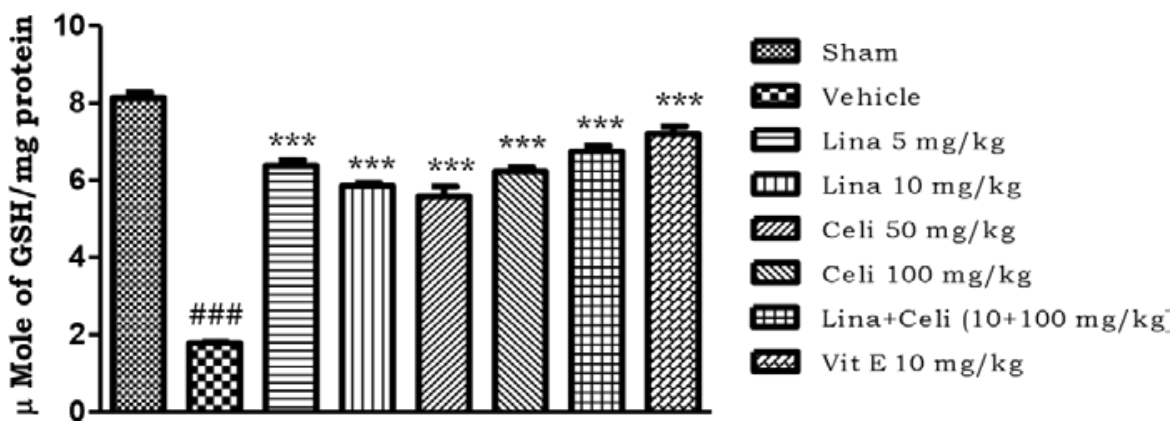

Fig. 5: Effect of linagliptin and celiprolol on reduced glutathione level, each column represents the mean \pm SEM of a shift in the reduced glutathione $(\mathrm{n}=6) .{ }^{\# \# \#<0.001}$ vs sham and ${ }^{* * *} \mathrm{p}<0.001$ vs vehicle

Effect of linagliptin and celiprolol on superoxide dismutase (SOD) level in rat brain

Vehicle group resulted in a significant decrease in the SOD level as compared to the sham group $(\mathrm{p}<0.001)$. Treatment with linagliptin
$(5 \mathrm{mg} / \mathrm{kg}$ and $10 \mathrm{mg} / \mathrm{kg})$ and celiprolol $(50 \mathrm{mg} / \mathrm{kg})$ both alone as well as in combination at doses $10 \mathrm{mg} / \mathrm{kg}$ and $100 \mathrm{mg} / \mathrm{kg}$ respectively, showed significant increase in SOD level $(p<0.001$ each), when analyzed with one-way ANOVA. [Treatment $\mathrm{F}(7,39)=$ $37.24, p<0.0001 ; n=6$ ] as compared to vehicle group (fig. 6). 


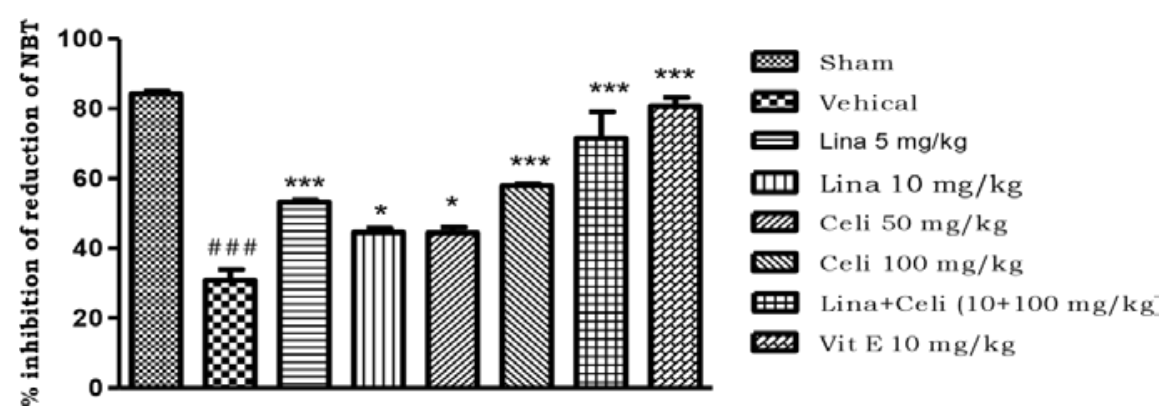

Fig. 6: Effect of linagliptin and celiprolol on SOD level, each column represents mean \pm SEM of the shift in\% inhibition of reduction of NBT $(\mathrm{n}=6)$. \#\#\#p<0.001 vs sham and ${ }^{*} \mathbf{p}<0.05,{ }^{* * *} \mathbf{p}<0.001$ vs vehicle

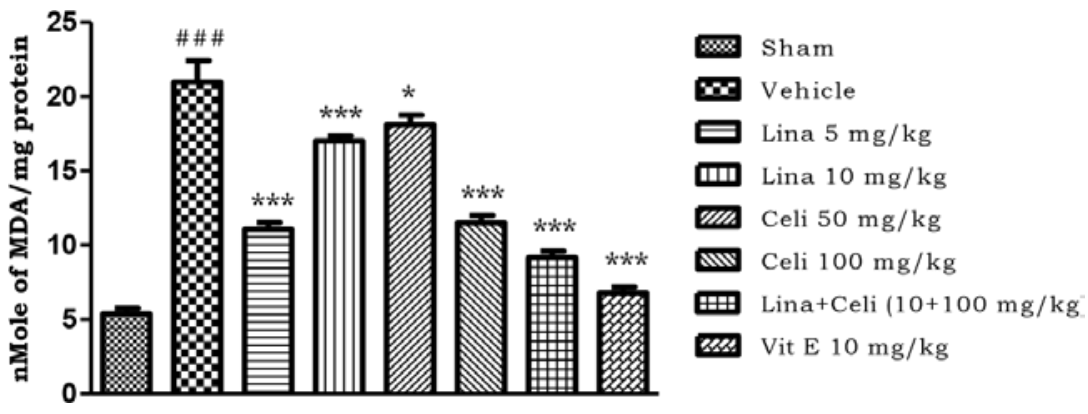

Fig. 7: Effect of linagliptin and celiprolol on LPO level, each column represents the mean \pm SEM of the shift in the level of LPO ( $n=6$ ), $\# \# \# \mathbf{p}<0.001$ vs sham and ${ }^{*} \mathbf{p}<0.05,{ }^{* * *} \mathbf{p}<0.001$ vs vehicle
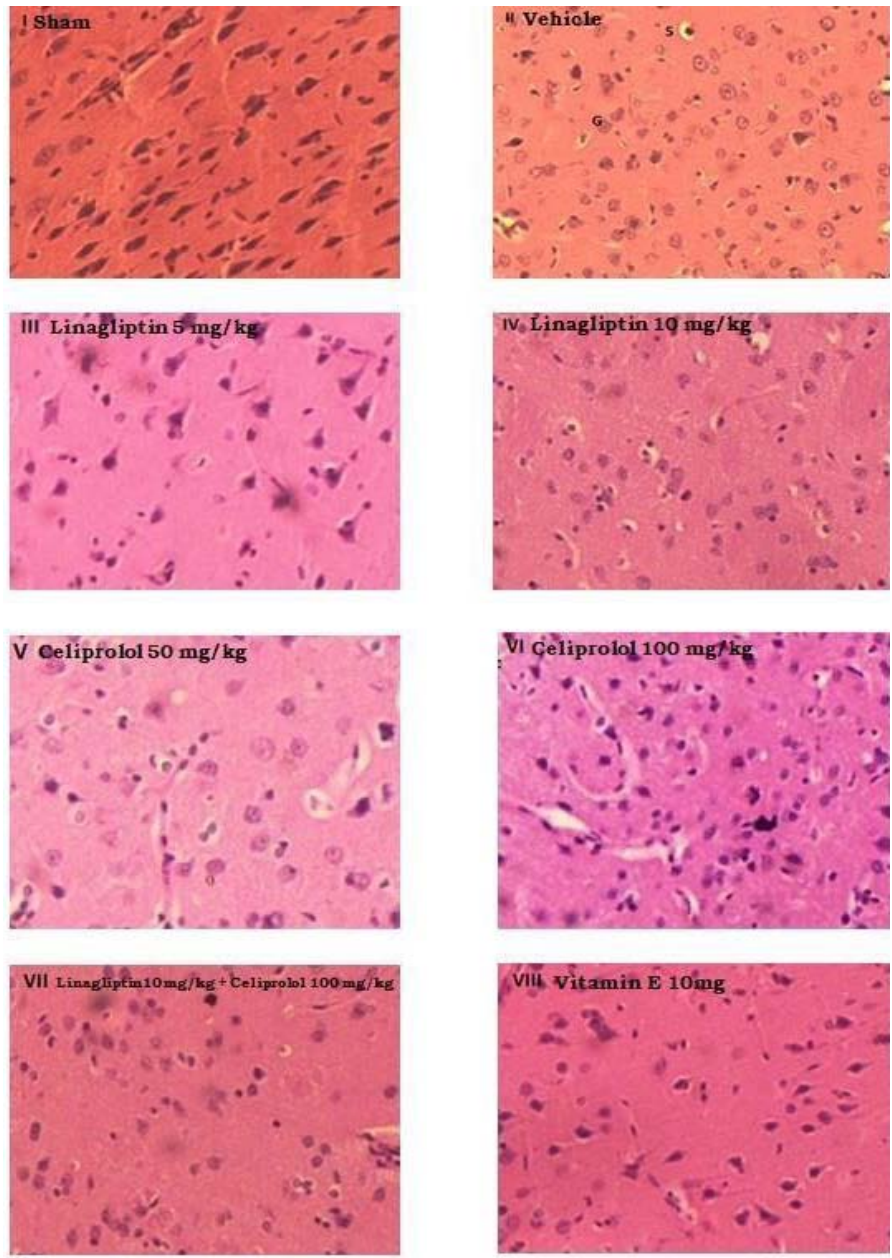

Fig. 8: Histopathological changes in the cerebral cortex of rats in different groups of reserpine-induced orofacial dyskinesia model 
Effect of linagliptin and celiprolol on lipid peroxidation (LPO) level in rat brain

Vehicle group resulted in a significant increase in LPO level as compared to the sham group $(\mathrm{p}<0.001)$. Treatment with linagliptin $(5 \mathrm{mg} / \mathrm{kg}$ and $10 \mathrm{mg} / \mathrm{kg})$ and celiprolol $[50 \mathrm{mg} / \mathrm{kg}(\mathrm{p}<0.05)$ and $100 \mathrm{mg} / \mathrm{kg}$ ] both alone as well as in combination at doses 10 $\mathrm{mg} / \mathrm{kg}$ and $100 \mathrm{mg} / \mathrm{kg}$ respectively, showed significant reduction in LPO level ( $\mathrm{p}<0.001 \mathrm{each})$, when analyzed with one-way ANOVA. [Treatment $\mathrm{F}(7,39)=73.51, \mathrm{p}<0.0001 ; \mathrm{n}=6]$ as compared to vehicle group (fig. 7).

\section{Histopathological analysis}

ISham group, the histopathological structure of the cerebral cortex showing normal architecture. II: Vehicle-treated group revealed the presence of ghost cells (G), vacuolated cytoplasm (S). III (Linagliptin $5 \mathrm{mg} / \mathrm{kg}$, p. o.), IV (Linagliptin $10 \mathrm{mg} / \mathrm{kg}$, p. o.), V(Celiprolol 50 $\mathrm{mg} / \mathrm{kg}$, p. o.), VI (Celiprolol $100 \mathrm{mg} / \mathrm{kg}$, p. o.), VII(Linagliptin10 $\mathrm{mg} / \mathrm{kg}+$ Celiprolol $100 \mathrm{mg} / \mathrm{kg}$ ) and VIII (Vitamin E $10 \mathrm{mg} / \mathrm{kg}$, p. o.) showed less number of ghost cells, vacuolated cytoplasm compared with the control group (fig. 8).

\section{Rotenone-induced neurodegeneration}

\section{Effect of linagliptin and celiprolol on motor activity}

The motor activity was examined $24 \mathrm{~h}$ after the last rotenone injection. Vehicle group resulted in a significant decrease in falling latency as compared to the sham group $(\mathrm{p}<0.001)$. Treatment with linagliptin $[5 \mathrm{mg} / \mathrm{kg} \quad(\mathrm{p}<0.001)$ and $10 \mathrm{mg} / \mathrm{kg} \quad(\mathrm{p}<0.05)]$ and celiprolol $[100 \mathrm{mg} / \mathrm{kg}(\mathrm{p}<0.01)$ but not $50 \mathrm{mg} / \mathrm{kg}]$ both alone as well as in combination at doses $10 \mathrm{mg} / \mathrm{kg}$ and $100 \mathrm{mg} / \mathrm{kg}$ respectively, showed significant reduction in falling latency $(\mathrm{p}<0.001)$, when analyzed with one-way ANOVA. [Treatment F $(7,39)=40.91$, $\mathrm{p}<0.0001 ; \mathrm{n}=6$ ] as compared to vehicle group (fig. 9).

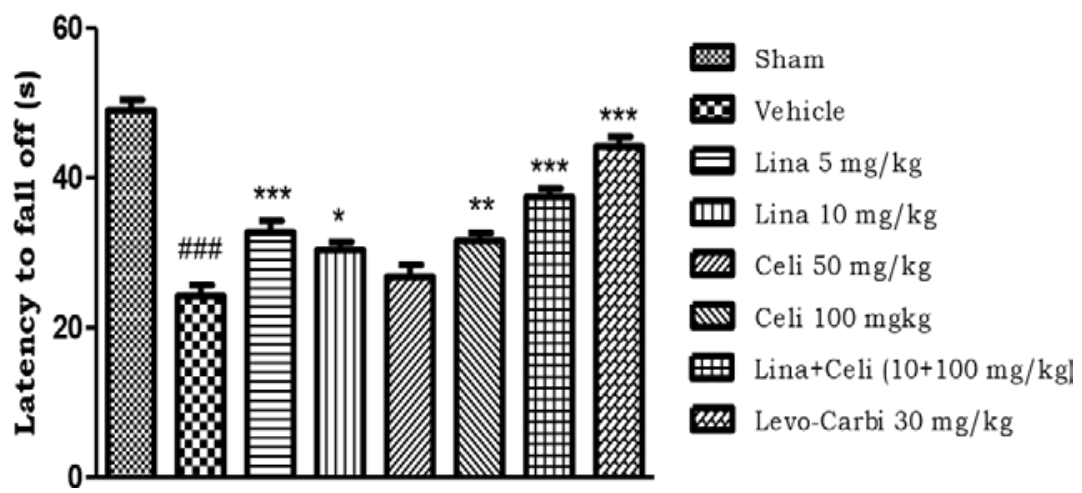

Fig. 9: Effect of linagliptin and celiprolol on motor activity, each column represents the mean \pm SEM of a shift in falling latency ( $n=6$ ). $\# \#$ ${ }^{\# \#}<0.001$ vs sham and ${ }^{*} \mathbf{p}<0.05,{ }^{* *} \mathrm{p}<0.01,{ }^{* * *} \mathrm{p}<0.001$ vs vehicle

Effect of linagliptin and celiprolol on number of pokings in hole board test

The number of pockings in the hole board test was examined $24 \mathrm{~h}$ after the last rotenone injection. Vehicle group resulted in a significant decrease in the number of pockings as compared to the sham group $(\mathrm{p}<0.001)$. Treatment with linagliptin $[5 \mathrm{mg} / \mathrm{kg}(\mathrm{p}<0.001)$ and 10 $\mathrm{mg} / \mathrm{kg}(\mathrm{p}<0.01)]$ and celiprolol $(50 \mathrm{mg} / \mathrm{kg}$ and $100 \mathrm{mg} / \mathrm{kg}$ ) both alone as well as in combination at doses $10 \mathrm{mg} / \mathrm{kg}$ and $100 \mathrm{mg} / \mathrm{kg}$ respectively, showed significant reduction in number of pockings $(\mathrm{p}<0.001 \mathrm{each})$, when analyzed with one-way ANOVA. [Treatment $\mathrm{F}$ $(7,39)=13.42, p<0.0001 ; n=6]$ as compared to vehicle group (fig. 10).

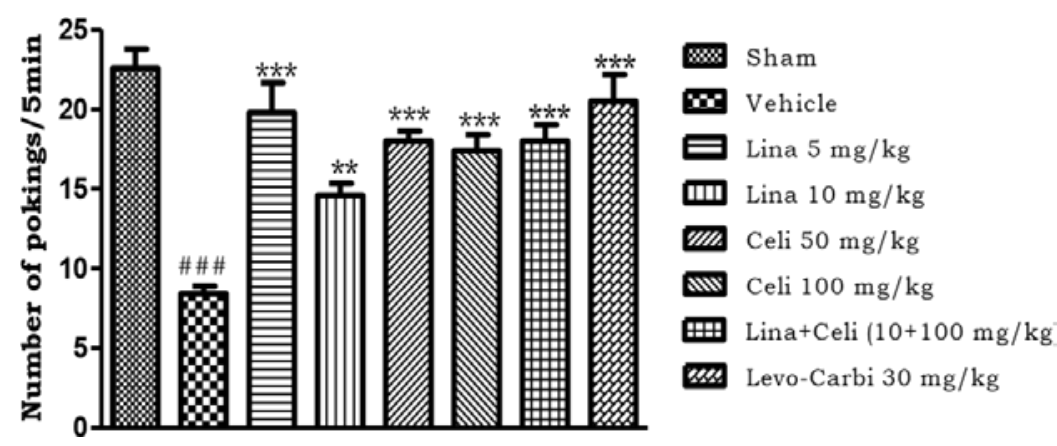

Fig. 10: Effect of linagliptin and celiprolol on a number of pockings in a hole-board test, each column represents mean \pm SEM of the shift in $(n=6) .{ }^{\# \# \#} p<0.001$ vs sham and ${ }^{* * *} p<0.001$ vs vehicle

\section{Biochemical parameters}

All biochemical parameters were examined $24 \mathrm{~h}$ after the last rotenone injection by sacrificing the rat after behavioral paradigms.

Effect of linagliptin and celiprolol on catalase (CAT) level in rat brain

Vehicle group resulted in a significant decrease in catalase levels as compared to the sham group $(\mathrm{p}<0.001)$. Treatment with linagliptin at dose $5 \mathrm{mg} / \mathrm{kg}$ and $10 \mathrm{mg} / \mathrm{kg}$ showed a significant increase in catalase levels $(p<0.001)$ and celiprolol at a dose of $50 \mathrm{mg} / \mathrm{kg}$ and
$100 \mathrm{mg} / \mathrm{kg}$, showed a significant increase in catalase levels $(\mathrm{p}<0.001)$. Moreover, both drugs in combination at doses $10 \mathrm{mg} / \mathrm{kg}$ and $100 \mathrm{mg} / \mathrm{kg}$ respectively, showed a significant increase in catalase levels $(p<0.001)$, when analyzed with one-way ANOVA. $[$ Treatment $F(7,39)=27.69, \mathrm{p}<0.0001 ; \mathrm{n}=6]$ as compared to vehicle group (table 1).

Effect of linagliptin and celiprolol on reduced glutathione (GSH) level in rat brain

The vehicle showed a significant decrease in GSH as compared to the sham group $(\mathrm{p}<0.001)$. Treatment with linagliptin $(5 \mathrm{mg} / \mathrm{kg}$ and 10 
$\mathrm{mg} / \mathrm{kg}$ ) and celiprolol (50 mg/kg and $100 \mathrm{mg} / \mathrm{kg}$ ) both alone as well as in combination at doses $10 \mathrm{mg} / \mathrm{kg}$ and $100 \mathrm{mg} / \mathrm{kg}$ respectively, showed significant increase in GSH level $(\mathrm{p}<0.001$ each), when analyzed with one-way ANOVA. [Treatment $F(7,39)=57.94$, $\mathrm{p}<0.0001 ; \mathrm{n}=6$ ] as compared to vehicle group (table 1 ).

Effect of linagliptin and celiprolol on superoxide dismutase (SOD) level in rat brain

Vehicle group resulted in a significant decrease in the SOD level as compared to the sham group ( $\mathrm{p}<0.001)$. Treatment with linagliptin 5 $\mathrm{mg} / \mathrm{kg}$ but not $10 \mathrm{mg} / \mathrm{kg}$ and celiprolol $50 \mathrm{mg} / \mathrm{kg}(\mathrm{p}<0.05)$ and 100 $\mathrm{mg} / \mathrm{kg}$ both alone as well as in combination at doses $10 \mathrm{mg} / \mathrm{kg}$ and $100 \mathrm{mg} / \mathrm{kg}$ respectively, showed significant increase in SOD level $(\mathrm{p}<0.001$ each), when analyzed with one-way ANOVA. [Treatment $\mathrm{F}(7,39)=37.24, \mathrm{p}<0.0001 ; \mathrm{n}=6]$ as compared to vehicle group (table 1).

Effect of linagliptin and celiprolol on lipid peroxidation (LPO) level in rat brain

Vehicle group resulted in a significant increase in LPO level as compared to the sham group $(\mathrm{p}<0.001)$. Treatment with linagliptin (5 $\mathrm{mg} / \mathrm{kg}$ and $10 \mathrm{mg} / \mathrm{kg}$ ) and celiprolol [50 mg/kg and $100 \mathrm{mg} / \mathrm{kg}$ ] both alone as well as in combination at doses $10 \mathrm{mg} / \mathrm{kg}$ and $100 \mathrm{mg} / \mathrm{kg}$ respectively, showed significant reduction in LPO level ( $p<0.001$ each), when analyzed with one-way ANOVA. [Treatment $F(7,39)=39.90$, $\mathrm{p}<0.0001 ; \mathrm{n}=6$ ] as compared to vehicle group (table 1 ).

Table 1: Effect of linagliptin and celiprolol on catalase level, reduced glutathione level, SOD and LPO level in rotenone-induced neurodegeneration model, ${ }^{\# \#} p<0.001$ vs Sham, ${ }^{*} p<0.05$ vs vehicle and ${ }^{* * *} p<0.001$ vs vehicle

\begin{tabular}{|c|c|c|c|c|}
\hline Treatments & $\begin{array}{l}\text { CAT }(\mu \text { Mole of } \mathrm{H} 202 \\
\text { decomposed } / \mathrm{min} / \mathrm{mg} / \text { protein) }\end{array}$ & $\begin{array}{l}\text { GSH } \\
\text { ( } \mu \text { Mole/mg protein) }\end{array}$ & $\begin{array}{l}\text { SOD (\% inhibition of } \\
\text { reduction of NBT) }\end{array}$ & $\begin{array}{l}\text { MDA (nMole } \\
\text { of MDA/mg protein) }\end{array}$ \\
\hline Sham & $7.616 \pm 0.241$ & $10.57 \pm 0.49$ & $86.21 \pm 1.03$ & $5.93 \pm 0.78$ \\
\hline Vehicle & $4.002 \pm 0.327 \# \# \#$ & $4.48 \pm 0.09 \# \# \#$ & $57.50 \pm 2.51 \# \# \#$ & $20.88 \pm 1.45^{\# \# \#}$ \\
\hline Lina 5 mg/kg & $7.046 \pm 0.238^{* * *}$ & $9.18 \pm 0.13^{* * *}$ & $77.95 \pm 2.51^{* * *}$ & $7.36 \pm 0.52^{* * *}$ \\
\hline Lina $10 \mathrm{mg} / \mathrm{kg}$ & $5.442 \pm 0.202^{* * *}$ & $7.48 \pm 0.19 * * *$ & $60.93 \pm 3.09$ & $14.18 \pm 1.45^{* * *}$ \\
\hline Celi $50 \mathrm{mg} / \mathrm{kg}$ & $5.858 \pm 0.233^{* * *}$ & $7.09 \pm 0.25^{* * *}$ & $67.16 \pm 2.09 *$ & $14.50 \pm 0.56^{* * *}$ \\
\hline Celi 100 mgkg & $5.764 \pm 0.163^{* * *}$ & $9.22 \pm 0.19 * * *$ & $75.04 \pm 2.16^{* * *}$ & $7.5 \pm 0.36^{* * *}$ \\
\hline Lina+Celi $(10+100 \mathrm{mg} / \mathrm{kg})$ & $6.760 \pm 0.242^{* * *}$ & $8.73 \pm 0.14^{* * *}$ & $78.68 \pm 2.20^{* * *}$ & $6.62 \pm 0.48^{* * *}$ \\
\hline Levo-Carbi $30 \mathrm{mg} / \mathrm{kg}$ & $7.570 \pm 0.186^{* * *}$ & $9.38 \pm 2.22^{* * *}$ & $81.20 \pm 1.36^{* * *}$ & $6.44 \pm 0.41^{* * *}$ \\
\hline
\end{tabular}
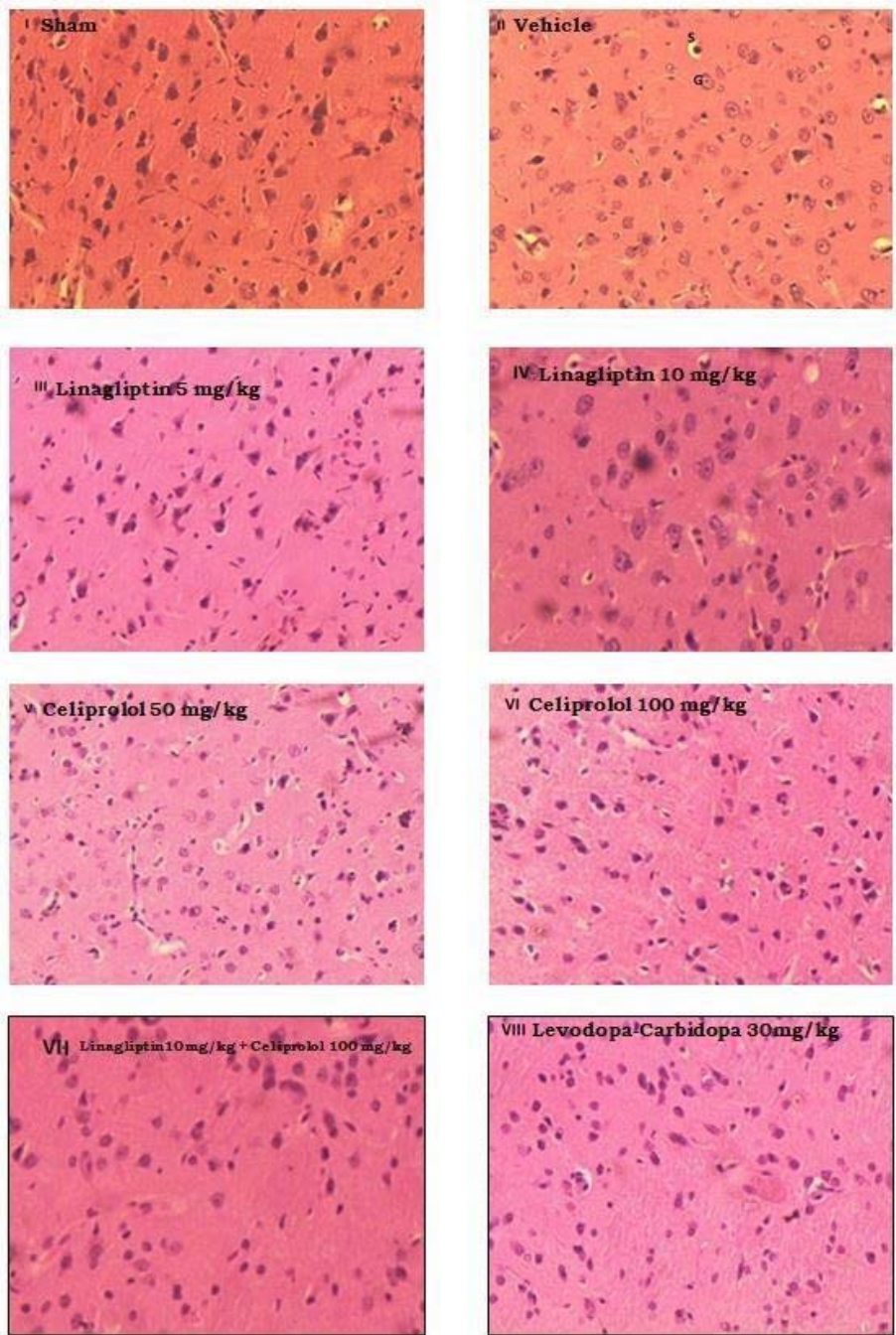

Fig. 11: Histopathological changes in the cerebral cortex of rats in different groups in the rotenone-induced neurodegeneration model 


\section{Histopathological analysis}

ISham group, the histopathological structure of the cerebral cortex showing normal architecture.

II: Vehicle-treated group revealed the presence of ghost cells (G), vacuolated cytoplasm (S).

III (Linagliptin $5 \mathrm{mg} / \mathrm{kg}$,po.), IV (Linagliptin $10 \mathrm{mg} / \mathrm{kg}$,po.), V(Celiprolol $50 \mathrm{mg} / \mathrm{kg}$,po.), VI (Celiprolol $100 \mathrm{mg} / \mathrm{kg}$,po.), VII(Linagliptin $10 \mathrm{mg} / \mathrm{kg}+$ Celiprolol $100 \mathrm{mg} / \mathrm{kg}$ ) and VIII (Vitamin E $10 \mathrm{mg} / \mathrm{kg}$,po.) showed less number of ghost cells, vacuolated cytoplasm compared with the control group (fig. 11).

\section{DISCUSSION}

Neurodegenerative disorders primarily affect the nervous system. Neurodegeneration is a condition in which cells of the brain and spinal cord are lost. These disorders raised due to many conditions like protein misfolding and aggregation, oxidative stress and free radical formation, metal dyshomeostasis, mitochondrial dysfunction, and phosphorylation impairment [20].

In the present study, we have used the reserpine-induced orofacial dyskinesia model and rotenone-induced neurodegeneration model. Acute administration of reserpine causes an increase in dopamine turnover that reflects oxidative metabolism of dopamine, the rise of which results in the production of metabolites of dopamine, dopamine quinones and hydrogen peroxide that promote lipoperoxidation. Reserpine also causes depletion of brain catecholamines leading to an akinetic state in experimental animals [21] Neisewanderandcoworkers have suggested that reserpineinduced oral dyskinesia may provide a new model for tardive dyskinesia [22] likewise rotenone is an active agent of pesticides that damages complex I of the mitochondrial respiratory chain and thereby induces nigrostriatal degeneration. It is also responsible for the generation of reactive oxygen species (ROS) during dopamine (DA) metabolism in dopaminergic neurons. Rotenone activates both mitochondrial and endoplasmic reticulum-dependent caspases that induce apoptosis [23] rotenone-treated rats demonstrated many characteristics of PD, including selective nigrostriatal dopaminergic degeneration, the formation of ubiquitin and $\alpha$-synuclein-positive nigral inclusions, and motor deficits [24].

VCMs and tongue protrusions are considered the major signs of orofacial dyskinesia [25]. In the present study, reserpine $(1 \mathrm{mg} / \mathrm{kg})$ (Vehicle group) significantly increased the frequency of VCMs and tongue protrusion compared to sham-operated rats. Vit. E, linagliptin, and celiprolol significantly attenuated the increase in vacuous chewing movements and tongue protrusions caused by acute exposure to reserpine. Similarly, locomotor activity is an index of alertness of mental activity as most of the drugs acting on CNS, influence locomotor activity. In the reserpine model, it was measured with the help of photoactometer, which operates on photoelectric cells that are connected with a circuit with the counter. Many authors [18) have used interruption of light beams as a measure of movements of rats in a cage. The total locomotor activity was significantly reduced in the vehicle-treated group as compared to the sham group. Administration of Vit. E, linagliptin, and celiprolol showed significant improvement in locomotor activity. All the animals were submitted to the hole board test to quantify changes in exploratory ability [26]. The exploratory ability gradually deteriorated in rotenone-treated animals but was unchanged in the sham group, the exploratory ability significantly increased in levodopa-carbidopa, linagliptin, and celiprolol treated groups, as compared to vehicle group. The rotarod test was used to assess muscle strength and balance [34]. We found that rotenone-treated rats showed decreased balance compared to the sham group, levodopa-carbidopa, linagliptin and celiprolol treated animals showed increased balance as compared to the vehicle-treated group.

Oxidative damage can be described as a consequence of insufficient antioxidant potential or excessive oxidative stress [27]. Exposure to free radicals from a variety of sources has led organisms to develop a series of defense mechanisms [28], out of which, enzymatic and non-enzymatic defense systems are prominent. Enzymatic antioxidant defenses include superoxide dismutase (SOD), glutathione peroxidase (GPx), catalase (CAT), etc. Nonenzymatic antioxidants are represented by ascorbic acid (Vitamin $\mathrm{C}$ ), $\alpha$ tocopherol (Vitamin E), glutathione (GSH) and other antioxidants. Reserpine treated animals showed elevated levels of lipid peroxidation along with a significant reduction in antioxidant enzymes such as SOD, CAT, and GSH indicating the generation of free radicals. However, administration of Vit. E or levodopa-carbidopa, linagliptin, and celiprolol significantly attenuated this reduction in enzymatic defense generated against free radicals and increase in lipid peroxidation, suggesting its possible antioxidant action

$\mathrm{H}$ and $\mathrm{E}$ stains nuclear and non-nuclear cell components and thereby provides morphological information about the cell [29]. In histopathological findings, the morphological changes seen after rotenone and reserpine treatment were suggestive of neuronal damage. The vehicle-treated group showed the presence of ghost cells (G) and vacuolated cytoplasm (S) when compared with the sham group. Whereas Vit. E or levodopa-carbidopa, linagliptin, and celiprolol treated rats showed less number of ghost cells and vacuolated cytoplasm when compared with the vehicle-treated group, this indicated that linagliptin and celiprolol have a protective role against reserpine-induced orofacial dyskinesia and rotenoneinduced neurodegeneration as shown by the standard drugs Vit. E or levodopa-carbidopa respectively. Thus, linagliptin and celiprolol may be used as neuroprotective agents. Further studies are necessary to unravel the mechanism of actions of both drugs at a molecular level, which will substantiate their uses in humans.

\section{FUNDING}

Nil

\section{AUTHORS CONTRIBUTIONS}

All the author has contributed equally.

\section{CONFLICT OF INTERESTS}

\section{Declared none}

\section{REFERENCES}

1. Hoglund K, Salter H. Molecular biomarkers of neurodegeneration. Expert Rev Mol Design 2013;13:845-61.

2. Wojsiat J, Zoltowska KM, Laskowska Kaszub K, Wojda U. Oxidant/antioxidant imbalance in Alzheimer's disease: Therapeutic and Diagnostic Prospects. Oxidative Medicine and Cellular Longevity; 2018. p. 1-16.

3. Shim JS, Kim HG, Ju MS, Choi JG, Jeong SY, Oh MS. Effects of the hook of Uncariarhynchophylla on neurotoxicity in the 6hydroxydopamine model of Parkinson's disease. J Ethnopharmacol 2009;126:361-5.

4. Hritcu L, Foyet HS, Stefan M, Mihasan M, Asongalem AE, Kamtchouing P. Neuroprotective effect of the methanolic extract of hibiscus asper leaves in the 6-hydroxydopaminelesioned rat model of Parkinson's disease. J Ethnopharmacol 2011;137:585-91.

5. Miller RL, James Kracke M, Sun GY, Sun AY. Oxidative and inflammatory pathways in Parkinson's disease. Neurochem Res 2009;34:55-65.

6. Danielson SR, Andersen JK. Oxidative and nitrative protein modifications in Parkinson's disease. Free Radical Biol Med 2008;44:1787-94.

7. Dong Y, Wang J, Feng DY, Qin HZ, Wen $\mathrm{H}$, Yin ZM, et al. Protective effect of quercetin against oxidative stress and brain edema in an experimental rat model of subarachnoid hemorrhage. Int J Med Sci 2014;11:282-90.

8. Gengler S, Mcclen P. GLP-1 rescues synaptic plasticity and reduces dense core plaques in APP/PSI mice. Neurobiology 2012;33:265-76.

9. Jayasankar K, Lixia G, Kin YT. Linagliptin, a dipeptidyl peptidase inhibitor, mitigates cognitive deficits and pathology in the 3xTg-AD mouse model of Alzheimer's disease. Mol Neurobiol 2016;321:975-83.

10. Kroller Schon S, Knorr M, Hausding M, Oelze M, Schuff A, Schell $\mathrm{R}$, et al. Glucoseindependent improvement of vascular dysfunction in experimental sepsis by dipeptidyl-peptidase 4 inhibition. Cardiovasc Res 2012;96:140-9. 
11. Wongchai K, Schlotterer A, Lin J, Humpert P, Klein T, Hammes $\mathrm{HP}$, et al. Protective effects of liraglutide and linagliptin in C. elegans as a new model for glucose-induced neurodegeneration. Horm Metab Res 2015;48:70-5.

12. Chaykovska L, Alter ML, von Websky K, Hohmann M Tsuprykov 0, Reichetzeder C, et al. Effects of telmisartan and linagliptin when used in combination on blood pressure and oxidative stress in rats with 2-kidney-1-clip hypertension. J Hypertens 2013;31:2290-9.

13. Yao EH, Fukuda N, Matsumoto T, Katakawa M, Yamamoto C Han Y, et al. Effects of the antioxidative $\beta$-blocker celiprolol on endothelial progenitor cells in hypertensive rats. Am J Hypertension 2008;21:1062-8.

14. Nishioka S, Yoshioka T, Nomura A, Kato R, Miyamura M, Okada $\mathrm{Y}$, et al. Celiprolol reduces oxidative stress and attenuates left ventricular remodeling induced by hypoxic stress in mice. Hypertension Res 2013;36:934-9.

15. Gurel A, Coskun O, Armutcu F, Kanter M, Ozen OA. Vitamin E against damage caused by formaldehyde in frontal cortex and hippocampus: biochemical and histological studies. J Chem Neuroanat 2005;29:173-8

16. Argyriou AA, Chroni E, Koutras A, Ellul J, Papapetropoulos S, Katsoulas G, et al. Vitamin E for prophylaxis against chemotherapy-induced neuropathy: a randomized controlled trial. Neurology 2005;64:26-31.

17. Keltner NL, Zielinski AL, Hardin MS. Drugs used for cognitive symptoms of Alzheimer's disease. Perspect Psychiatry Care 2001;37:31-4.

18. Vogel HG, Scholkens BA, Sandow J, Muller G, Vogel Wf. Drug discovery and evaluation: Pharmacological Assays. 2nd ed. Springer Verlag, Berlin, Germany; 2002. p. 595-643.

19. Naidu PS, Singh A, Kulkarni SK. Effect of withaniasomnifera roots extracts on haloperidolinduced orofacial dyskinesia: a possible mechanism of action. J Med Food 2003;26:107-14.

20. Shaikh S, Snobar S. Neurodegenerative disease: multifactorial conformation disease and their therapeutic interventions. J Neurodegen Dis 2003;13:1-8.
21. Carlsson A, Lindqvist $\mathrm{M}, \quad$ Magnusson $\mathrm{T}$. 3, 4dihydroxyphenylalanine and 5-hydroxytryptophan as reserpine antagonists. Nature 1957:180:1200-3.

22. Neisewander JL, Castaneda E, Davis DA. Dose-dependent differences in the development of induced oral dyskinesia in rats: support for a model of tardive dyskinesia. Psychopharmacol 1994;116:79-84.

23. Betarbet R, Sherer T, Mackenzie G, Garcia Osuna M, Panov A Greenamyre Jt. Chronic systemic pesticide exposure reproduces features of Parkinson's disease. Nat Neurosci 2000;3:1301-6.

24. Verma R, Nehru B. Effect of centrophenoxine against rotenoneindued oxidative stress in an animal model of Parkinson's disease. Neurochem Int 2009;55:369-75.

25. Burger ME, Alves A, Callegari L, Athayde FR, Nogueira CW, Zeni $\mathrm{G}$, et al. Ebselen attenuates reserpine-induced orofacial dyskinesia and oxidative stress in rat striatum. Prog Neuropsychopharmacol Biol Psychiatry 2003;27:135-40.

26. Coulom H, Birman S. Chronic exposure to rotenone models sporadic Parkinson's disease in Drosophila melanogaster. J Neurosci 2004;24:10993-8.

27. Chow CK. Nutritional influence on cellular antioxidant defense systems. Am J Clin Nutr 1979;32:1066-81.

28. Cadenas E, Davies KJA. Mitochondrial free radical generation, oxidative stress, and aging. Free Radical Biol Med 2000;29:222-30.

29. Li Y, Powers C, Jiang N, Chopp M. Intact, injured, necrotic and apoptotic cells after focal cerebral ischemia in the rat. J Neurol Sci 1998;156:119-32.

30. Luck H. Methods of enzymatic analysis. Academic Press: New York: 1971. p. 885-93.

31. Ellman GL. Tissue sulfhydryl groups. Arch Biochem Biophys 1959;82:70-7.

32. Kono Y. Generation of superoxide radical during autooxidation of hydroxylamine and an assay for superoxide dismutase. Arch Biochem Biophys 1978;186:189-95.

33. Wills ED. Mechanism of lipid peroxide formation in animal tissues. Biochem J 1966;99:667-76.

34. Lapointe N, St-Hilaire M, Martinoli Mg, Blanchet J, Gould P, Rouillard C, et al. Rotenone induces non-specific central nervous system and systemic toxicity. FASEB J 2004;18:717-9. 